\title{
Abolishing the Insanity Defense: A Look at the Proposed Federal Criminal Code Reform Act in Light of the Swedish Experiencet
}

\author{
by
}

\author{
Ralph Reisner* and Herbert Semmel**
}

The only certain thing that can be said about the present state of knowledge and therapy regarding mental disease is that the science has not reached the finality of judgment . . . .

The Criminal Code Reform Act ${ }^{2}$ proposed by the Nixon administration represents the most significant attempt in the United States to eliminate the insanity defense in its present form. The Act would establish instead a system in which the power to determine a defendant's fate-imprisonment, hospitalization, or release-is effectively in the hands of psychiatrists. Under the Act, inental disease or defect is a defense only if it precludes the defendant from having the state of mind constituting an element of the offense charged. ${ }^{3}$ This provision effectively eliminates the present insanity defense, because under the general culpability sections of the Act, absence of the requisite state of mind, for whatever reason, is a bar to prosecution. ${ }^{4}$ The effect on trials would be to make psychiatric testimony crucial to determining whether or not a defendant had committed a criminal act, for the terms "mental disease or defect" would inevitably require expert explication. The Administration proposal also provides procedures for determining the disposition of cases involving persons who are imcoinpetent to stand trial, who are mentally ill and found guilty of crimes,

i A grant from the Social Science Research Council and the University of Illinois Center for International Comparative Studies provided the financial support for the collection of empirical data upon which a part of this Article is based.

* B.A. University of Washington, 1952; LL.B. George Washington, 1958. Professor of Law, University of Illinois.

*:; B.S. New York University, 1950; LL.B. Harvard 1953. Attorney, Center for Law and Social Policy, Washington, D.C.

1. Greenwood v. United States, 350 U.S. 366, 375 (1956) (Frankfurter, J.).

2. S.1400, 93d Cong., 1st Sess. (1973).

3. Id. $\S 502$.

4. Id. $\S 302(\mathrm{~b})$. 
who are mentally ill at the conclusion of their prison terms, or who are acquitted because mental disease prevented them from forming the state of mind required as an element of a charged offense. ${ }^{5}$ These proposals are markedly similar to the provisions of the new Swedish penal code of $1965,{ }^{6}$ which made Sweden the first western nation to abolish the insanity defense ${ }^{7}$ in favor of a system in which inental abnormality only goes to the question of disposition, not of guilt. ${ }^{8}$

Much of the hiterature on the mental condition of criminal defendants focuses only on the insanity defense, with debate centering on the role of individual culpability, its relation to the deterrent effect of the criminal law, and its infusion of morality into the determination of guilt. ${ }^{9}$ This focus is too narrow. A defendant's inental condition may be an issue not only during trial, but also in other proceedings,

5. Id. $\S \S 4221-25$ (1973).

6. Law of Dec. 21, 1962, No. 700, Criminal Code, [1962] S.F.S. 1837 (Swed.) [hereinafter cited as BrB]. While the present penal code did not become effective until Jan. 1, 1965, it was formally adopted on Dec. 21, 1962.

7. Cf. Burgess, Progress or Retreat, 9 TRIAL 16 (1973).

8. BrB, supra note 6 , ch. $31, \S 3$. Certain abnormal mental states can, however, lead to a finding that the necessary intent was missing and that therefore no crime was committed. See note 23 infra.

9. In this context, the debate about the significance of mental condition is an extension of a more fundamental conflict about the ultimate function of the criminal law. Under what is known as the deterrence model, law-conforming behavior is the end result of a complex socializing process which depends on various conscious and unconscious identifications and, at least in part, on the integration of many culturallydetermined concepts, including the notion of blameworthiness and its parent concept of personal responsibility. The adjudication of guilt and innocence in its traditional form is one of the mechanisins by which acceptance of these concepts is reinforced. The insanity defense, in turn, serves to differentiate between offenders who are presumed to have diminished control over their actions and therefore cannot be termed blameworthy or guilty, and those who are capable of controlling their behavior and consequently can be blamed. Reasoning from this model, abolition of the insanity defense would remove the connection between responsibility and guilt, thereby reducing the deterrent potential of the criminal law. See generally A. Goldstein, The INSANITX Defense 12-13 (1967) [hereinafter cited as Goldstein]; H. PACKer, The Limits of the CRIMINal SANCtion 10 (1968) [hereinafter cited as PACKer].

The other dominant position, which has been labeled the behaviorist viewpoint, perceives criminal behavior as a form of psychiatric or social maladjustment. The principal function of the criminal law is to define the conditions under which social intervention to effect readjustment is permissible. Intervention involves selection by an appropriate agency of one of several treatment modalities for the social offender. Unlike the deterrence model, which focuses on the offense and minimizes individualized response, the behaviorist model calls for diaguostic and predictive judgment at various stages of the criminal process. Behaviorists see deterrence, with its reliance on punishment, as both meffective and archaic, the remnant of a dated legal system which placed a premium on retribution. S. GlueCK, CRIME AND CORRECTION 94 (1952); H. MaNheim, Criminal Justice and Social Reconstruction 223-37 (1946); P. Roche, The Criminal Mind 273.74 (1958); B. Wootton, Crime and the Criminal Law chs. 2 \& 3 (1963); Knight, The Meaning of Punishment, in HANdBooK of Correctronal PsYchology 675 (R.M. Linder et al. eds. 1947). 
such as hearings on competency to stand trial or civil commitment proceedings utilized as an adjunct to the criminal process. Moreover, the procedure by which the evaluation of mental condition is rendered and the respect that evaluation is accorded are as important in determining a defendant's fate as is the theoretical definition of insanity or even the abolition of the traditional insanity defense. Evaluation procedures and the role of the so-called impartial psychiatric witness will therefore be the focus of the following discussion.

In Sweden, the decision whether a person who has engaged in antisocial conduct and who displays evidence of inental abnormality will be imprisoned, hospitalized, or freed (and perhaps required to undergo outpatient counseling or psychiatric treatment) is effectively placed in the hands of doctors in the forensic-medical division (Rättslakkarradet) of the social welfare administration (Socialstyrelsen). A decision of the local medical administrative board regarding civil commitment is final, and no judicial review is available. ${ }^{10}$ In cases arising through the criminal justice process, the prosecutor and judge have some de jure powers, but they cannot order hospitalization without the concurrence of the state psychiatrio agency. ${ }^{11}$ As will be shown below, the effective locus of decision-making in Sweden is generally a single psychiatrist employed full time or part time by the state inental health system.

In the United Statcs, determining whether the mentally ill defendant will be imprisoned is generally in the hands of the jury, if the defendant raises the insanity defense and requests a jury trial. ${ }^{12}$ If the jury rejects the imsanity defense, the judge is likely to sentence the defendant to prison. ${ }^{13}$ The alternative of probation accompanied

10. Admission and discharge decisions are the responsibility of administrative agencies and are entirely outside the purview of judicial control or supervision. The initial decision as to admission or discharge is made by a hospital physician, except that when admission is made through the criminal judicial process, any discharge must be approved by a discharge cornmittee. Law of June 16, 1966, No. 293, Concerning the Provision of In-Patient Psychiatric Care in Certain Cases, $\$ \S 8,17,23,[1966]$ S.F.S. 687 (Swed.) [hereinafter cited as Mental Health Law of 1966, translated in 19 INT'L Dig. of Health LEg. 221 (1968). An adverse decision by the physician can be appealed to a local discharge committee (Utskrivningsnämnden). Id. $\$ 21$. A decision by the discharge committee may be further appealed to a psychiatric committee (Psykiatriska Nämnden). Id. $\S 22$. The psychiatric committee has a menbership of five, imcluding two physicians, a person with judicial experience, and two lay persons. Id. $\$ 28$. The decision of the committee is final and not reviewable in any court of law.

11. BrB, supra note 6, ch. $31, \S 3$.

12. The independence of the jury determination may depend upon the manner in which psychiatric information is transinitted to the jury, that is, whether it is presented by psychiatrists called by the state and the defendant as adversaries or by a state-appointed "inpartial expert." See text accompanying notes 105-11 infra.

13. The experience in the District of Columbia over a ten-year period (1952-62) 
by counseling exists but is rarely used, partly because the insanity defense most often is raised in cases involving dangerous crimes ${ }^{14}$ and partly because of the very limited outpatient community counseling facilities which are available. ${ }^{15}$ Once a defendant is sentenced to prison, the decision to remove him from a conventional prison to one for the criminally insane is generally regarded as the responsibility of prison administrators. ${ }^{16}$

If the defendant is found not guilty by reason of insanity, involuntary hospitalization inay be ordered by either the judge or jury, depending on state law. ${ }^{17}$ In addition, the judge may effectively convert a criminal proceeding into a commitment proceeding by finding that the defendant is incompetent to stand trial and a danger to limself or otliers. ${ }^{18}$

Under the Administration proposals, 10 the "impartial psychiatric expert" would be introduced-just as in Sweden-at virtually every stage of the decisionmaking process. ${ }^{20}$ In Sweden, the result of the

suggests that in most cases when mental state is in issue and a court-ordered examination is performed and the suspect thereafter pleads or is found to be guilty, imprisoninent will ensue. In the ten-year period studied, approximately 87 percent of such defendants were imprisoned; only seven percent were placed on probation or given suspended sentences. Judicial Conference of the District of Columbia Circuit, Re-

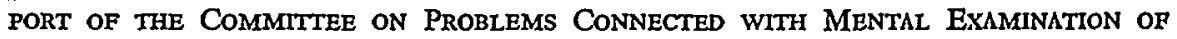
the ACCused in Criminal Cases, Before Trial 168 (1966).

14. A. Matthews, Mental Disability and the Criminal Law 32 (1970) [hereinafter cited as MATTHEws]; Diamond, The Fallacy of the Impartial Expert, 3 ArChIVEs CRIM. Psychodynamics 221, 229 (1959) [hereinafter cited as Diamond.

15. Chambers, Alternatives to Civil Commitment of the Mentally Ill: Practical Guides and Constitutional Imperatives, 70 Mich. L. Rev. 1108, 1115 n.38 (1972).

16. See, e.g., 18 U.S.C. $\$ \S 4081,4241,4242$, 4243; Rosheisen v. Steele, 193 F.2d 273 (8th Cir. 1951); but see U.S. ex rel. Schuster v. Herold, 410 F.2d 1071 (2d Cir. 1969).

17. See the summary of state laws in Lynch v. Overholser, 369 U.S. 705, 72528 (1962) (Clark, J., dissenting), cited in GolDSTEIN, supra note 9, at 143.

18. In such a case, standards or procedures different from those used in de jure civil commitment proceedings may now be constitutionally foreclosed. See Jackson v. Indiana, 406 U.S. 715 (1972).

19. S. 1 , 93d Cong., 1st Sess. §§ 3-11C3, $-11 C 5,-11 C 6,-11 C 8,-11 D 2$ (1973); S. 1400, 93d Cong., 1st Sess. §§ 4221-25 (1973).

20. Under the proposed legislation, if the defendant indicates that he will introduce evidence of his insanity at the time of the offense charged, the court may order him examined by two psychiatrists. S. 1400, 93d Cong., 1st Sess. $\$$ 4221(b) (1973). Their reports are presumably admissible. See note 164 infra. If the defendant is acquitted by reason of insanity, the court must hold a hearing to determine whether he should be hospitalized, and again two court-designated psychiatrists are to examine the defendant and determine "whether the acquitted person is presently suffering from a mental disease or defect as a result of which his release would create a substantial danger to himself or to the person or property of others." Id. $\$ 4222(\mathrm{c})(1973)$. If the defendant is found guilty, he may petition for a hearing on his current mental condition. Id. § 4224. Again psychiatric reports will be ordered. Id. $\S 4224(\mathrm{~b})$, (c). Releases from inental institutions similarly require hearings, $i d$. $\S 4222(f)$, as do com- 
new system has been the transfer of effective decisionmaking regarding a defendant's fate into the hands of psychiatrists. The same result would likely follow in the Umited States under the current federal proposals, drastically altering the traditional model of decisionmaking by judge and jury.

We beheve such a development to be undesirable. It rests on the premise that psychiatrists or other behavioral scientists can rehably and validly determine mental status, susceptibility to treatment, and future behavior. This premise is contradicted by substantial empirical evidence that psychiatrists and clinicians have widely differing notions of what constitutes mental illness and, particularly, the appropriate diagnosis to be attached to given symptoms and behavior; that there is little agreement on how to treat or cure mental illness, inuch less predict susceptibility to treatment; and that psychiatrists have hittle ability to predict future conduct, particularly dangerousness. There is no one correct psychiatric opinion which even an impartial psychiatrist can give in any particular case, and presenting psychiatric judgments to a judge or jury as "impartial" encourages them to discount any testimony that might be given by a defendant's "own" expert and evade the difficult evaluation of factual data which, in light of the unreliability of expert opinion, must be done. Furthermore, psychiatrists base their opinions in part on the same kind of information a lay person uses in evaluating another individual, such as prior hospitalization and the amount of violence displayed in the criminal act. ${ }^{21}$ Such imformation can be understood and analyzed by a jury, with psychiatrists assisting by indicating what details are relevant to the jury's inquiry and explaining their significance in the context of psychiatric theory and practice. The jury can also serve as a check on institutional bias ${ }^{22}$ and can infuse commonsense community values into determinations of mental condition and criminal responsibility. These are traditional roles for the jury, and they should not be abandoned for the chimerical certainty of "impartial" expert judgments.

The procedural system which is best adapted to revealing disagreement annong psychiatrists and subjecting it to lay evaluation is our traditional adversary systein. The adversary process requires that the court-appointed psychiatrist be called by whichever party wishes

mitments following expiration of a defendant's sentence. Id. $\$ 4225$.

The Act provides that at most hearings the defendant shall be represented by counsel (provided at the government's expense if the defendant is indigent) and have the opportunity to testify, present evidence, subpoena witnesses, and confront and crossexamine witnesses who appear. See id. \$ 4221(d). Whether the defendant's rights include the means to hire and right to call a defense psychiatrist is not clear.

21. See tables in part III infra.

22. See, e.g., Duncan v. Louisiana, 391 U.S. 145, 156 (1968). 
to utilize his testimony and that he not be identified in any manner as "impartial." In addition, the defendant whose mental condition is in issue and who cannot afford the services of a psychiatrist must be provided with the means to engage an independent expert who can advise him on preparation for trial, including cross-examination of opposing experts, and testify on his behalf. Only by maintaining such adversarial safeguards will we permit and encourage the jury to perform its proper function.

\section{USE OF EXPERT OPINION IN THE UNITED STATES}

In the United States, psychiatrists are frequently called upon to render diagnoses when a defendant's mental condition is in issue, and when testifying as witnesses they are asked to offer psychiatric opinions in terms of legal standards. The ultimate issue on which a psychiatric opimion is sought depends on the stage of the criminal proceeding. Even before the commencement of criminal proceedings, psychiatrists may evaluate a suspect's mental status as a possible basis for waiving prosecution;, ${ }^{23}$ but given the breadth of prosecutorial discretion, it is difficult to generalize about the type of psychiatric findings that lead to civil rather than criminal disposition.

Once prosecution is initiated, psychiatrists may be utilized to determine the defendant's conpetency to stand trial, the issue being whether at the time of trial the defendant is insane or otherwise so inentally incompetent as to be unable to understand the proceedings against him or properly assist in his own defense. ${ }^{24}$ If during the trial the defendant raises the defense of insanity, the psychiatrist is asked to express his opinion on whether at the time of the crime the defendant was suffering a defect of reason from a disease of the mind so as not to know the nature and quality of his act; or, if he did know it, whether he did not know that what he was doing was wrong. ${ }^{25}$ If the defendant is found not guilty by reason of insanity, the psychiatrist may be asked whether the acquitted person is then "suffering from a inental disease or defect as a result of which his release would create a substantial danger to himself or to the person or property of

23. F. Mnler, Prosecution: The Decision to Charge A Suspect with $A$ CRIME 213 (1969).

24. See, e.g., Jackson v. Indiana, 406 U.S. 715 (1972).

25. In those jurisdictions that adhere to the classical M'Naghten Rule, the test is articulated in these or similar terms. AMerican Bar Foundation, The MeNTally DISABLED AND THE LAW 379-80 (S. Brakel \& R. Rock eds. 1971) [hereinafter cited as American Bar Foundation Study]; Goldstern, supra note 9, at 45-46. Where other tests, such as the Model Penal Code formulation, are employed, the criteria are somewhat different. American Bar Foundation Study at 380-84; GoldsTeIN at 66-87. 
others."26 A similar opinion is required when the mental state of a prisoner about to be released is questioned. ${ }^{27}$ Finally, at the dispositional stage of trials, psychiatrists may be called upon to testify to whether a convicted defendant is suffering from a mental disease or defect and whether he is in need of care or treatment in a inental institution or confinement in an institution for the "criminally insane." 28 Thus, at many stages of the criminal process, expert psychiatric opinion is sought by the court or proffered by the defense to help the judge or jury decide whether a defendant falls within certain legally defined categories of incompetence, mental disease, or insanity.

II

\section{Determining Mental Abnormality Under Swedish Penal LaW}

The descriptive model of the Swedish system and the findings presented here are based on data collected over a two-year period (1969-70). One of the authors spent a total of ten months in Sweden directing the data-collection phase of the study, which consisted of numerous interviews with judges, prosecutors, forensic psychiatrists, officials of the Ministry of Justice, and administrative personnel associated with the psychiatric services division of the social welfare administration. General statistical data was provided by the Swedish statistical bureau (Statistiska Centralbyran).

An analysis was made of the case files of all criminal cases that were referred for psychiatric evaluation in 1967. Approximately 900 case files containing the reports of examining psychiatrists and supporting documents (and follow-up infornation when requested) were made available after a protracted and elaborate clearance procedure required under Swedish law. ${ }^{29}$ Each case file was reviewed by a teain made up of three Swedish research assistants with backgrounds in the behavioral sciences. A psychiatrist associated with the institution where the files were reviewed was available to act as a consultant to the team personnel. Information abstracted from the case files was transposed onto precoded questionnaires containing 120 informational categories. ${ }^{30}$ These data were subjected to various types of statisti-

26. See, e.g., Bolton v. Harris, 395 F.2d 642, 647 (D.C. Cir. 1968).

27. See, e.g., Baxtrom v. Herold, 383 U.S. 107 (1966).

28. See, e.g., Schuster v. Herold, 410 F.2d 1071 (2d Cir. 1969).

29. Law of May 28, 1937, No. 249, Concerning Limitations on Obtaining Public Documents, $\S \S 11,14$, [1937] S.F.S. 489 (Swed.).

30. These categories integrated both background data for each person examined (including employment, personal history, education, psychiatric and medical history, and prior criminal conduct) as well as a variety of other data, including that pertaining 
cal analysis. ${ }^{31}$

\section{A. The Legislative Framework}

The new Swedish penal code, which went into effect January 1 , 1965 , is the culmination of more than twenty-five years of preparatory work by various commissions. ${ }^{32}$ One of its signal changes is the convictability of everyone who "imtentionally"33 commits a criminal act. This departs from prior law, which provided that "no one may be held to answer for an act which he committed under the influences of mental disease, feeblemindedness or other abnormality of such a profound nature that it must be regarded as the equivalent to mental disease."34 By the omission of this provision in the new code, no inquiry into the defendant's state of mind for the purpose of assessing criminal responsibility is allowed, except to determine whether the defendant's conduct was purposeful. ${ }^{35}$

The legislative history makes it clear that parliamentary intent was to eradicate the long-standing distinction between "responsible" and "nonresponsible" criminal conduct. ${ }^{36}$ Rejection of this distinction and the derivative notion of blameworthiness was intended to emphasize that the only legitimate ends of the criminal law are individual

to the particular offense that triggered the psychiatric examination and the resulting diagnostic findings and recommendations.

31. Frequency distribution tables provided a general profile in terms of the salient characteristics of those within the various subgroups established by the psychiatric decision-making process. These categories are described in the text accompanying notes 144-46 infra. Where intracategory differences emerged, the relationship in terms of the dependency of selected variables was tested by the application of a chi-squaro test method of analysis. See generally D. OWEN, Handbook of Statistical Tadles 510 (1968).

32. B. BörJeson, OM På̈öljders Verkaningar 206 (1966) (Swed.); T. Sellin, The Protective Code, A Swedish Proposal 7-8 (1957) [hereinafter cited as Sellin].

33. BrB, supra note 6 , ch. $1, \S 2$.

34. Sellin, supra note 20 , at 19.

35. When the crime charged requires specific intent but the suspect's abnormal mental condition rendered him incapable of forming such intent, he will be acquitted. As in the United States, the dinensions of this "defense" are not well defined. Sce generally W. LAFAVE \& A. ScotT, CRIMTnal LAW 192-94 (1972). It is only rarely raised in Sweden, and only three appellate cases have considered the issue. Judginent of Sept. 25, 1969, [1968] N.J.A. 401 (Swed.); Judgment of Dec. 9, 1968, [1968] N.J.A. 500 (Swed.); Judgment of Dec. 9, 1968, [1968] N.J.A. 471 (Swed.). While the defense was sustained in one case, none of these decisions by the Swedish supreme court throws much light on the scope of this doctrine under Swedish law. See generally II Law Council Commentary of 1962, [1962] N.J.A. 368, 394-95, 499; JäREBORG, HANDLING OCH UPPSAT (1960) (Swed.); III KoMMENTARER TILL BRoTTSBALKEN 225-26 (1967) (Swed.) Sellin, supra note 20, at 19.

36. II Law Council Commentary of 1962, [1962] N.J.A. 368, 394-95, 499 (Swed.) (Minister of Justice's comments on proposed penal code submitted to law council of the parliament (Riksdag)); SELliN, supra note 20, at 19. 
rehabilitation and general deterrence. ${ }^{37}$ Retribution was to be totally rejected as one of the purposes of the penal law. Apart from this didactic purpose, the parliament also intended the elimination of the distinction between responsible and nonresponsible criminal conduct to bring the theoretical framework of the criminal law more closely into correspondence with social and psychiatric reality. ${ }^{38}$

The new code, however, draws an important distinction between mentally abnormal and other offenders. Those who commit a criminal act "under the influence of mental disease, feeblemindedness, or other mental abnormality that must be considered equivalent to mental disease"39 are subject to a different range of sanctions than other offenders. ${ }^{40}$ The principal difference is that mentally abnorinal offenders cannot be sentenced to prison, whereas offenders found not mentally abnormal cannot be sentenced to involuntary psychiatric hospitalization. ${ }^{41}$ Both groups of offenders are subject to fines or probation. ${ }^{42}$

No offender determined to be mentally abnormal can be hospitalized unless the examining physician declares the offender to be in need of psychiatric care. ${ }^{43}$ The standards used for determining whether psychiatric hospitalization is necessary are those of the civil commitunent statute. ${ }^{44}$ In addition to having the requisite inental abnormality, the subject must nneet one of five criteria authorizing hospitalization in civil commitment cases. ${ }^{45}$ However, since these criteria are fairly broad, there is ample latitude to find a basis for psychiatric care when the offender is found to be mentally abnormal as defined by the penal code.

37. II Law Council Commentary of 1962, [1962] N.J.A. 368, 394-95, 499 (Swed.) See generally B. BörJESON, OM PAFÖLJDERS VeRKNINGAR 206 (1966) (Swed.).

38. Minister of Justice's comments, supra note 24, at 394-95, 499; Sellin, supra note 20 , at 19.

39. BrB, supra note 6, ch. $33, \S 2$.

40. In addition to the forms of mental abnormality which bring an offender within the reacl of $\mathrm{BrB}$, supra note $6, \mathrm{ch} .33, \S 2$, the Swedish penal code contains other provisions which, for purposes of the imposition of sanctions, involve consideration of the offender's mental condition. Thus, mental abnormalities which are not equivalent to a "mental disease" may in some circumstances lead to reduced penalties. Id. $\mathrm{ch} .33, \S 4$. Similarly, under certain limited circumstances an alcoholic offender may be relieved of the normal sanction that would be applicable and instead placed under the supervision of a civil agency having responsibility for the care and treatment of alcoholics. Id., ch. $31, \S 2$. The code also authorizes commitment to a psychiatric hospital in place of other sanctions when the offender becomes mentally ill after the commission of the criminal act. Id., ch. $31, \S 3$.

41. BrB, supra note 6, ch. $33, \S 2$.

42. Id.

43. Id., chs. 31-33.

44. Kungl. Medicinalstyrelsens Cirkulär (Royal Medical Board Circular) of Mar. 20, 1967, § 5, [1967] M.F. 16 (Swed.).

45. Mental Health Law of 1966, supra note $10, \S 1$. 


\section{B. The Forensic-Psychiatric Examination Process}

\section{Organization of the Forensic-Psychiatric System}

A group of special institutions within the structure of the social welfare administration (Socialstyrelsen) constituting what is called the forensic-psychiatric system, has been entrusted with the task of determining the inental condition of criminal defendants ${ }^{40}$ and, in appropriate cases, evaluating defendants' need for special treatment. ${ }^{47}$ In 1972 there were five evaluation clinics, two located within prisons and three associated with psychiatric hospitals. ${ }^{48}$ Seven evaluation "stations," which evaluate only persons not in custody, were located throughout the country. ${ }^{49}$

Psychiatric evaluations are submitted to the courts in the form of written reports based on either a comprehensive forensic-psychiatric workup or a more limited examination known as the Section-7 examination. ${ }^{50}$ Since a defendant rarely exercises his right to introduce expert medical opinion and since the courts are reluctant to stray from the findings of the psychiatric report, these reports are usually conclusive on the question of the defendant's mental state.

\section{Personnel}

While the system includes physicians, psychologists, social workers, office workers, and others, it is totally controlled by the forensic psychiatrist. Sweden has recognized the special status of the forensic psychiatrist by making the field a licensed specialty; thus, the Swedish title has a formal meaning, in contrast to the United States, where any psychiatrist can style himself a forensic psychiatrist. To qualify, a doctor must complete a general psychiatric residency of two years and work for one year as a physician at one of the system's clinics or stations, ${ }^{51}$ in addition to his regular medical training.

46. See generally Statens Offentliga Utredningar (Public Report) of 1959, No. 20, Det Rättspsykiatriska Undersökningsväsendets Organisation, Concerning the Forensic Psychiatric System, [1959] S.C.U. (Swed.).

47. Law of June 16,1966, No. 301, Concerning Forensic Psychiatric Examinations in Certain Cases, \& 5, [1966] S.F.S. 703 (Swed.).

48. Kungl. Maj:ts Instruktion (Royal Instruction) of Nov. 25, 1966, No. 632, [1966] S.F.S. 1413 (Swed.); Kungl. Medicinalstyrelsens Kungörelse (Royal Medical Administration Directive) of Dec. 30, 1966, No. 832, [1966] S.F.S. 832 (Swed.).

49. Kung1. Maj:ts Kungörelse (Royal Directive) of May 14, 1970, No. 178, 3, [1970] S.F.S. 386 (Swed.).

The forensic-psychiatric system is undergoing reorganization. The two prison clinics, which are presently directed by the Correctional Administration, are scheduled to be transferred to the Social Health and Welfare Administration, which already directs all the other clinics and stations.

50. Law of June 29, 1964, No. 542, Concerning Background Investigations in Criminal Cases, \& 7, [1964] S.F.S. 255 (Swed.).

51. Kungl. Maj:ts Instruktion (Royal Instruction) of May 23, 1969, No. 221, 
In recent years the system has employed an average of 28 fulltime forensic psychiatrists. ${ }^{52}$ Each examines and evaluates an average of only 18 persons each year. ${ }^{53}$ Because of this low productivity and because of staff shortages within the system, approximately 40 percent of the psychiatric evaluations are performed by part-time consultants from private practice. ${ }^{54}$

\section{Referrals to the System}

In Sweden, there are two stages at which the criminal justice system takes cognizance of the mental condition of a defendant. At the investigatory stage, the prosecutor may request a court-ordered forensic-psychiatric evaluation which may ultimately result in a waiver of prosecution upon the hospitalization of the accused.55 Once prosecution has been initiated, the court may order a forensic-psychiatric report which may result in hospitalization or outpatient counseling in lieu of imprisonment. ${ }^{56}$ This order may be made on the court's own initiative or at the request of either the prosecutor or the defendant.5T If neither the prosecutor nor defense counsel requests a psychiatric referral, the court's attention may be directed to the issue of mental abnormality by the recommendations contained in the background investigation report that is prepared by an employee of the court. This

$\S 12$, [1969] S.F.S. 489 (Swed.). While the statutory provisions speak only of a psychiatric residency of two years duration, the requirement that at least one year involve work with one of the systems' clinics or stations has been imposed as a matter of administrative practice. Interview with executive secretary of the Forensic Psychiatric Review Board (Rättsläkarrådet).

52. Utredning angående de rättspsykiatriska undersökningarna (Socialstyrelsen) 1 (1971) (Swed.) (Report concerning forensic psychiatric examination system) [heremafter cited as Working Group Report].

53. Id. at 10.

54. Id., Bilaga (Appendix) 3, Tabell (Table) 2. The forensic psychiatric system, particularly present examination procedures, has recently been the subject of severe criticism by both lay groups and the medical-psychiatric profession in Sweden. The criticism, however, has mainly focused on examination procedure, which is regarded as unnecessarily time-consuming and expensive. Several commentators have suggested that adequate diagnostic results could be achieved by the utilization of general psychiatrists (instead of psychiatrists specialized in forensic psychiatry as at present) and by significantly reducing the scope and time of the examinations. S. NyCANDER, AvsKaffa RäTTSPSYKIATRIN (1970) (Swed.); OTTOSON, II L L̈̈KARTIDNINGEN 132, 134 (1968) (Swed.); Palmgren, XX Lärartidningen 2264, 2266 (1970) (Swed.); Swedish PsYCHIATRIC AsSOCIATION REPORT, XXI LÄKARTIDNINGEN 2389, 2391 (1970) (Swed.).

55. Rättegångsbalken of July 18, 1942, No. 740 , Code of Judicial Procedure, ch, 20, § 7(4), [1942] S.F.S. 1714 (Swed.) [hereinafter cited as RB]. An English transiation of the Code of Judicial Procedure can be found in A. BRUzELIUS \& $R$. Ginzburg, The Swedish Code of Judicial Procedure (1968).

56. Law of June 16, 1966, No. 301, Concerning Forensic Psychiatric Examination in Criminal Cases, \& 1, [1966] S.F.S. 703 (Swed.).

57. Id. 
report, which is similar to the presentencing report in the United States, is required whenever imprisonment for longer than six months is possible. ${ }^{58}$ It is difficult to generalize about the circumstances that might lead the staff person responsible for the preparation of this report to recommend a medical psychiatric referral. In many cases, the question of mental status is raised by a prior history of psychiatric treatment or hospitalization. In other instances, the defendant's behavior during the interview with the investigator nay signal the possibility of mental illness. ${ }^{50}$

Once the issue of mental abnormality is brought before the court, the judge may order either a Section 7 medical-psychiatric examination $^{60}$ or the inore ,comprehensive forensic-psychiatric examination. ${ }^{11}$ Approximately 3,000 Section 7 examinations are ordered each year, ${ }^{02}$ and they are usually performed by general practitioners. ${ }^{03}$ The physician submits a report on a two-page form, including an opinion on whether a forensic examination is necessary. Although the court inay order a forensic-psychiatric examination without a Section 7 report, it usually einploys the Section 7 examination as a screening device. In 1967, 74 percent of the 862 forensic-psychiatric examinations were preceded by Section 7 examinations. ${ }^{64}$ The preference for the more limited Section 7 examination reflects an awareness of the much greater financial cost of forensic-psychiatric examinations (ten times higher for the psychiatrist alone), ${ }^{65}$ as well as concern that the forensic-psychiatric examination is a more significant intrusion into a defendant's privacy.

A forensic-psychiatric examination nay be performed only by court order. ${ }^{68}$ There are three prerequisites. First, either the suspect's confession or conclusive evidence that he committed a criminal act must be proferred to the court. ${ }^{07}$ Second, the examination must

58. Law of June 29, 1964, No. 542, Concerning Personal Investigation of Suspects, § 7, [1964] S.F.S. 1255 (Swed.).

59. Interviews with court staff personnel in Stockholm and Lund, July 1971.

60. Law of June 29, 1964, No. 542, Concerning Personal Investigation of Suspects, § 7, [1964] S.F.S. 1255 (Swed.).

61. Law of June 16, 1966, No. 301, § 1, [1966] S.F.S. 703 (Swed.).

62. Working Group Report, supra note 40, at 20-21. Approximately 10 percent of all persons suspected or charged with a crime carrying a possible penalty in excess of six months imprisonment undergo a Section 7 examination.

63. Law of June 29, 1964, No. 542, Concerning Personal Investigation of Suspects, § 7, [1964] S.F.S. 1255 (Swed.).

64. Finding based on the 1967 sample. Sce text accompanying note 17 supra.

65. Working Group Report, supra note 40, at 5, 21. In 1971 physicians performing Section 7 exams received a flat fce of approximately \$50. Psychiatrists outside the system who perform forensic-psychiatric examinations receive a fee of approximately $\$ 500$. Id.

66. Law of June 16, 1966, No. 301, § 1, [1966] S.F.S. 703 (Swed.).

67. Id. $\S 2$. There need not be conclusive evidence that the suspect had the re- 
be expected to aid in determining what sanction should be imposed or in determining whether the suspect was able to form the required state of mind for commission of the crime charged. ${ }^{68}$ Third, the court must find that sanctions greater than a fine will follow a conviction. ${ }^{63}$ There is no specific provision giving a suspect the right to appeal ordering of a forensic-psychiatric examination, but such an order, like any other, can be attacked when it unnecessarily delays disposition of a case. ${ }^{70}$ An appeal, however, does not serve to stay the lower court decision.

The governing statute provides that forensic-psychiatric examinations shall be performed "as soon as possible" and that all psychiatric reports shall be filed with the court within six weeks from the time that a case has been referred. ${ }^{71}$ The Social Welfare Administration may, however, grant extensions for good cause. The six-week time limit has been repeatedly exceeded, and exceptions are granted routinely. ${ }^{72}$ In 1967, for instance, the examination time for those in custody averaged 20 weeks, and the time for those not in custody averaged 29 weeks. $^{73}$

\section{Examination Procedures and Reports}

A number of professionals participate in the evaluation process. The psychiatrist in charge of the case normally performs general physical and mental examinations of the defendant. The mental examination usually involves two or three interviews. ${ }^{74}$ Neurological tests, such as electroencephalograms, are administered in the clinic but normally referred to outside specialists for reading and evaluation. Social workers prepare a detailed background case history froin interviews with the defendant, his family, employers, and acquaintances. A battery of psychological tests is administered and evaluated by a staff psychologist. ${ }^{75}$

The psychiatrist has the responsibility of preparing a summary of the case file as well as the evaluation and recommendation section.

quired mens rea, as one of the fnnctions of the examination is to determine whether the suspect conld have formed the requisite criminal intent. III KOMMENTARER TILL BROTTSBALKEN 227-28 (1967).

68. Law of June 16, 1966, No. 301, § 2, [1966] S.F.S. 703 (Swed.). See also III KOMMENTARER TILL BROTTSBALKEN 228 (1967).

69. In certain limited instances this requirement may be disregarded. Law of June 16, 1966, No. 301, § 2, [1966] S.F.S. 703 (Swed.).

70. BrB, supra note $6, \mathrm{ch} .49, \S 6$.

71. Law of June 16, 1966, No. 301, § 4, [1966] S.F.S. 703 (Swed.).

72. Working Group Report, supra note 40, at 5-6.

73. Finding based on 1967 sample. See text accompanying note 17 supra.

74. Interviews with Dr. Karl Eric Tornquist, Stockholm, Nov. 6, 1970 and Dr. Ester Lurell, Uppsala, Nov. 18, 1970.

75. Id. 
A full report with attachments averages 40 double-spaced typed pages. Nearly all reports contain data such as psychological test results and evaluation, a social history, and an assessment by staff personnel. Each report includes a summary section approximately six to ten pages in length. Reference is normally made to the defendant's present mental state and his mental state at the time of the commission of the crime. If psychological abnormality is imdicated, the diagnostic category is given and an evaluation of dangerousness is made. Some effort usually is made to relate any psychological pathology to the defendant's genetic and social background. ${ }^{76}$

Finally, each report normally includes a specific finding that the defendant did or did not commit the crime under the influence of mental illness, mental retardation, or mental abnormality equivalent to inental disease. A second fimding addresses itself to the need for closed psychiatric treatment, open psychiatric treatment, or any other sanction allowable under the penal code. Since the need for psychiatric hospitalization must be evaluated from the perspective of the civil commitment statute, ${ }^{77}$ the report will ordinarily include a finding as to the specific statutory criterion that, in the opimion of the examining psychiatrist, warrants psychiatric hospitalization. There are five possible criteria, including a finding that the individual is dangerous to himself or others or to property, or that "he is clearly lacking in insight into the nature of the disease ... and his condition ... will become appreciably worse if care is not provided."78

\section{Review of the Forensic-Psychiatric Report}

The Social Health and Welfare Administration currently has a special board to review forensic examinations. ${ }^{79}$ In criminal cases review may be requested only by the court, which has complete discretion in the matter. ${ }^{80}$ The number of such court requests has been relatively small. In 1968 , only 10 percent (80) of the total reports were referred for review; in 1969, 12 percent (108) were referred. ${ }^{81}$

76. Finding based on 1967 sample. See text accompanying note 17 supra.

77. Kungl. Medicinalstyrelsens Cirkulär of March 20,1967, No. 16, § 5, [1967] M.F. (Swed.).

78. Mental Health Law of 1966, supra note 10, § 1. Additional grounds include: (1) "as a result of the disease, he is incapable of managing his own affairs" and (2) "as a result of the disease, his way of life is seriously disturbing to his neighbors or to other persons." Id.

79. Kungl. Maj:ts Instruktion of Nov. 25, 1966, No. 632, § 14, [1966] S.F.S. 1413 (Swed.); Kungl. Maj:ts Instruktion of Oct. 20, 1967, No. 606, \&\$16, 37, [1967] S.F.S. 1321 (Swed.).

80. Law of June 16, 1966, No. 301, Concerning Forensic Psychiatric Examination in Certain Cases, $\$ 6$, [1966] S.F.S. 703 (Swed.).

81. SINNESSJUKNÄMNDENS ÅRSBERÄTtTELSE För ÅR 1967 and 1968 (MENTAL Health Commission Manual Statistical Report) (Swed.). 
Ordinarily a case is reviewed on the record alone, but on rare occasions the board will request its forensic-psychiatric consultant to submit a supplementary report. In addition to these two procedures, the review board can request a reexamination by the original physician or order an additional examination by another physician. In nearly all cases, however, the review is based solely on a reading of the forensic-psychiatric report. Reviews take an average of two weeks. If the review board disagrees with the recommendations of the report, it merely enters a summary conclusion, and its underlying reasons are not given to either the court or the parties to the action. Approximately 20 percent of the cases referred to the board in 1967 were modified on review, but this represented only 2 percent of all cases referred for forensic-psychiatric examination. ${ }^{82}$

\section{Waiver of Prosecution}

While mental abnormality is no longer an excuse or defense under the penal code, certain forms of mental abnormality can be the basis for a waiver of prosecution. ${ }^{83}$ Although it was not until 1965 that legislation specifically authorized waiver of prosecution of mentally ill persons the practice itself is of relatively long standing. ${ }^{84} \mathrm{Be}-$ tween 1961 and 1965 waivers of prosecution accounted annually for between 50 and 65 percent of all cases in which defendants were freed from criminal liability or hospitalized because of mental abnormality. Since 1965 the percentage has consistently exceeded 60 percent, so that waiver of prosecution actually accounts for a majority of dispositions of criminal cases in which mental abnormality is found. ${ }^{85}$

While waiver of prosecution seems commonplace from an AngloAmerican perspective, it is an unusual development in Sweden, where uniform proseuction has traditionally been the rule. ${ }^{86}$ There are also fundamental differences in the legal effect that is accorded to waivers

82. Finding based on 1967 sample. See text accompanying note 17 supra.

83. BrB, supra note 6 , ch. $20, \S 7(4)$. See generally NeLson, INGRIPANDEN VID BRoTT (1970).

84. This practice, which was specifically authorized by the chief prosecutor, was carried out in disregard of the traditional legislative policy of uniform prosecution of offenders, and represented a relatively rare instance of such administrative departure from legislatively prescribed policy. Interview with Thorsten Cars, Assistant to Chief Prosecutor of Sweden, in Stockholm, Aug. 19, 1971.

85. The statistics presented here are the product of a combinatiou of sources. Statistics on the incidence of waivers of prosecution on grounds of mental abnormality were abstracted from the annual issues of Kriminal Statistic (prior to 1967, Brottsligheten) published and issued by the Statistiska Centralbyrån. The remaining statistical data were provided by the staff of the Statistiska Centralbyrån, to whom the authors wish to express their thanks.

86. See K. Imthner, Criminal Procedure in Sweden 59-61 (1966). See generally G. ELWING, TIILRÄCRLIGA SRÄL STUDIER ÖVER FörUTSÄTtNINGAR För ALLMÄNT Atal. (BASIS For Prosecution) (1960) (Swed.). 
in the two systems. In Sweden a waiver of prosecution may not be granted unless there is overwhelming evidence of the suspect's guilt. ${ }^{87}$ Generally, this level of proof requires that the suspect has confessed. Any decision to waive prosecution of a serious offense is made a matter of record and requires a formal report to the Ministry of Justicet. ${ }^{88}$

Three criteria must be inet before discretion to waive prosecution can be exercised: the First, abnormal condition upon which a waiver is predicated must correspond to a mental disease or its equivalent as defined in chapter 33-2 of the penal code; second, the criminal act must have been committed under the influence of the abnormal mental condition; and third, a waiver of prosecution must be followed by the suspect's psychiatric hospitalization. ${ }^{80}$ The first two conditions ensure that those who are granted waivers would, if they were prosecuted, meet the conditions of chapter 33-2 and be subject to the special range of sanctions provided for mentally abnormal offenders.

Once the prosecutor decides that a defendant's mental condition is a possible basis for waiver of prosecution, the actual decision whether or not waiver will occur effectively passes to the forensic psychiatrist. Although not expressly required by statute, by administrative construction a forensic-psychiatric report is a prerequisite to waiver. ${ }^{90}$ Since prosecution cannot be waived for mental condition unless the defendant is thereafter hospitalized, ${ }^{01}$ a psychiatrist's finding that no hospitalization is needed requires the prosecutor to continue with the prosecution. If the psychiatrist finds abnormality and recommends hospitalization, a waiver of prosecution normally follows. Although no statistical data were available to measure prosecutorial reliance on psychiatric reports, four prosecutors who were interviewed stated that they invariably waived prosecution when hospitalization was recommended. ${ }^{92}$

\section{The Trial Stage}

Unlike the United States, Sweden does not recognize the concept of incompetency to stand trial, and trials proceed regardless of the

87. Office of the Chief Prosecutor, Intra-office Guidelines, (concerning the application of RB $20 \mathrm{ch} .7, \mathrm{pt.}$ 4) (undated).

88. $I d$.

89. BrB, supra note 6 , ch. $20, \S 20(4)$.

90. Interview with Thorsten Cars, Assistant to the Chief Prosecutor of Sweden, in Stockholm, Aug. 19, 1971.

91. BrB, supra note 6 , ch. $20, \S 20(4)$. Hospitalization must be effected by commitment under one of two statutory provisions. Mental Health Law of 1966, supra note 10, or Law of Dec. 15, 1967, No. 940, Concerning Mentally Retarded Persons, [1967] S.F.S. 2045 (Swed.).

92. Interview with Deputy-Chief Prosecutor of Skona, Lund, Junc 24, 1968; Chief and Deputy-Chief Prosecutor of Malmo, Malmo, July 8, 1968; Chief Assistant Prosecutor of Sweden, Stockholm, August 7, 1971. 
ability of the defendant to understand or participate. The Swedish practice is less harsh than it may seem, for the truly imcompetent defendant will probably be found to have committed the crime in a condition of mental abnormality and be hospitalized rather than imprisoned, an end result similar to that in the United States. Moreover, short delays of a noonth or two are granted if there is evidence that a nonhospitalized defendant's mental condition might improve and permit him to participate more effectively..$^{93}$

At the trial, mental condition is relevant only to the issue of mens rea-whether the defendant acted "intentionally." Although no statistics are available, defenses based on lack of mens rea appear to be rare. Only three reported appellate cases dealt with the issue between 1965 and $1973 . .^{95}$

The courts' concern with the defendant's inental condition primcipally arises after a finding of guilt. If the crime is found to have been committed under the influence of mental disease, its equivalent, or feeblemindedness, the court cannot imprison the defendant. ${ }^{90}$ As will be shown below, the courts invariably follow the finding of the forensic-psychiatric report in this determination. The court may hospitalize the defendant if mental abnormality was present, but only if the forensic-psychiatric repont finds the defendant to be in need of treatment and hospitalization. ${ }^{97}$ If it does not, the only available sanctions are a fine or probation, which may include compulsory counseling at a community health center.

\section{III}

\section{THE IMPARTIAL EXPERT}

One of the most significant trends in American criminal trialsa development which parallels the Swedish experience-has been the introduction of the so-called impartial psychiatric expert into the decision-making process. In approximately half the states, ${ }^{98}$ and as proposed in the Criminal Code Reform Act, the judge has authority to

93. Rylander, Forensic Psychiatry in Relation to Legislation in Different Countries, in III Psychtatrie Der Gegenwart, Forschung und Praxis 397, 414 (H. Gruttle, R. Jung, W. Mayer-Gross, \& M. Müller eds. 1951).

94. BrB, supra note 6 , ch. $1, \S 2$. The insanity defense was repealed in 1965.

95. See cases cited in note 23 supra.

96. BrB, supra note 6 , ch. $33, \S 2$.

97. Id. Courts are also empowered in exceptional cases to order hospitalization when the criminal act was not committed under conditions of mental abnormality. Id. ch. $31, \S 3$ (permitting hospitakization although the defendant was not mentally ill at the time of the crime if he is found to be mentally ill at the time of sentencing).

98. Goldstenn, supra note 9, at 131; Guttmacher \& Weihofen, The Psychiatrist on the Witness Stand, 1952 BosT. U.L. REv. 287, 310 n.35 [hereinafter cited as Guttmacher \& Weihofen]. 
appoint one or more psychiatrists at public expense to examine the defendant. The judge can require the defendant to submit to an examination. ${ }^{99}$ We have concluded from our study of the Swedish system since 1965 and from other American studies that the presentation of psychiatric opinions to a judge or jury by court-appointed psychiatrists designated "inıpartial," rather than by psychiatrists called by and identified with the state or the defense as adversaries, shifts the decision-making power from the judge or jury to the testifying psychiatrists. We further conclude that this shift places excessive power over the life of an individual in the hands of a single psychiatrist, particularly in light of the lack of reliability inherent in psychiatric evaluations.

The Swedish study included an analysis and follow-up of the 847 cases that arose during 1967 in which a forensic-psychiatric examination was conducted. The recommendation of the examining psychiatrist, or of the review board (in the few cases in which the recommendation was modified on review), was followed by the court in 99 percent of the cases. ${ }^{100}$ The only divergence noted was that out of 346 persons recommended for hospitalization, eight were not committed. ${ }^{101}$ In the 501 cases where the recommendation was against lospitalization, Swedish law barred the court from ordering the defendant hospitalized.

While there is no coinparable statistical study on the extent to which judges follow the recommendations of court-appointed psychiatrist in the United States, the evidence available suggests that much the same practice prevails in the United States. One psychiatrist, Sheila Gray, reviewed extensive studies of practices in the District of Columbia and concluded that court-appointed psychiatrists "have been able to make the decisive determination in the vast inajority of insanity defense cases."102 Another researcher found that judges in one ostensibly representative jurisdiction unquestiomingly accepted the "independent" psychiatrist's evaluation when the defendant's competency to stand trial was in question. ${ }^{103}$ A study in California revealed that a majority of judges classified their function in civil commitment proceedings as "rubberstamp."104 One judge, testifying before a legislative committee, stated that in civil commitment cases judges "are

99. S.1400, 93d Cong., 1st Sess. § 4221(b) (1973).

100. Finding based on 1967 sample. See text accompanying note 17 supra.

101. Id.

102. Gray, The Insanity Defense: Historical Developments and Contemporary Relevance, 10 AM. Crim. L. Rev. 559, 580 (1972) [hereinafter cited as Gray].

103. MatTHEws, supra note 14, at 123; cf. Goldstein, supra note 9, at 132-33.

104. Kay, Farnham, Karren, Knakal \& Diamond, Legal Planning for the Mentally Retarded: The California Experience, 60 CALIF. L. REv. 438, 463 (1972). 
guided almost 100 percent by what the medical examiners testify to. . . . I hardly conceive of myself as putting myself up as a better medical expert than the examiners." 105 Dr. Gray further commented upon this judicial willingness to adopt the opinions of court-appointed psychiatrists:

One need only note the frequency with which trial judges depend solely upon the government psychiatrist to determine whether an indigent's mental condition warrants the appointment of a defense psychiatrist to recognize the imbalance of opposing forces. The degree of reliance placed on the opimions of the psychiatrists from Saint Elizabeths Hospital reflects a widely espoused opinion that these experts are more reliable than independent experts because they constantly observe the criminally insane, and more impartial, because they are public servants. The prevalence of these opinions suggests that the diagnostic procedures upon which the government psychiatrists' decisions are based reflect a higher degree of accuracy and inpartiality than those of their nongovernmental counterparts. But this is patently not the case. ${ }^{106}$

Juries generally determine the issue of mental condition when a defendant raises the insanity defense. The fact that the jury is the authorized decision-maker, however, does not mean that the jury actually makes the decisive finding. Whether the jury truly fulfills its decision-making function may depend on the manner in which expert psychiatric testimony is presented to it. Many states provide that when an insamity plea is raised, the defendant may be required to submit to a mental examination at the request of the prosecutor or the court, or the defendant may request the court to appoint a psychiatrist or tean of psychiatrists to examine him. ${ }^{107}$ If the defendant is indigent or lacks sufficient funds to pay for expensive psychiatric expert witnesses, there is no alternative in most states to the court-appointed psychiatrist. ${ }^{108}$

If the only expert witness at the trial is a court-appointed psychiatrist and the jury is made aware of that fact, there is a strong likelihood the jury will regard the psychiatrist as "impartial" and will adopt his opinion just as judges do. ${ }^{100}$ Guttmacher and Weihofen reported that jurors almost never find contrary to the opinion of the "impartial"

105. California Fact Finding Committee on Judiciary, Admission, Care and Treatment 13 (Jan. 1965), cited in Projects-Civil Commitment of the Mentally Ill, 14 U.C.L.A.L. REv. 822, 860 n.207 (1967).

106. Gray, supra note 100 , at $580-81$.

107. Thirty-one states and the District of Columbia authorize judicial appointment of impartial psychiatric examiners. GoldSTEIN, supra note 9, at 131.

108. Id. at 132, MATrHews, supra note 14 , at 40 .

109. GoldsTEIN, supra note 9, at 132. 
psychiatric witness. ${ }^{110}$ In Ohio, where court-appointed psychiatrists are authorized, the jury rejected the hospital's findings in only five cases out of inore than $1000 .{ }^{111}$ Similar results were reported in other states. ${ }^{112}$ Guttmacher and Weihofen concluded that the weight given to "inipartial" expert opinion is so great "lawyers have learned that it is usually hopeless to contest the hospital's findings." 113

The court appointment of psychiatrists thus effectively shifts the decision-1naking power from the court or jury to the psychiatrist, except in those rare cases where the defense has the ineans to retain its own experts and the appointed psychiatrists are not labeled as such. This shift has been advocated by soine and justified by others with the claim that an "impartial, conscientious ${ }^{114}$ psychiatric service carried out in the scientific atmosphere of a neutral court clinic" will better serve the ends of the law than "putting one group of hired experts against another similar group" before a body of nonscientific layinen. ${ }^{115}$ This argument rests on several premises: first, that the diagnostic and predictive process is scientific, that is, having soine unified theoretical framework capable of producing an acceptable level of reliability; ${ }^{116}$ second, that a state-operated psychiatric service is "impartial;" third, that the issue to be determined is purely a scientific one. The weakness of these premises will be explored below.

\section{A. Scientific Methodology and Reliability}

\section{General Problems}

Few scientific disciplines contain such a range of theories as clinical psychology and psychiatry. Freudian, Adlerian, Jungian, Sullivanian, Skinnerian and other schools compete with unusual ferocity for recognition as the authoritative formulation of human behavior. It has been noted that these schools "often seen more like religious sects or political parties than they do like scientific investigators." ${ }^{117}$ As

110. Guttmacher \& Weihofen, supra note 96 , at 313-14.

111. Id. at 313 .

112. Id. at $313-14$.

113. Id. at 314 .

114. Without discussing the question of conscientiousness, we merely note that in Sweden the system's full-time psychiatrists perform an average of only 18 examinations per year. Working Group Report, supra note 40, at 10-11.

115. Guttmacher \& Weihofen, supra note 96, at 318.

116. See generally Nagel, Methodological Issues in Psychoanalytic Theory, in J. Katz, J. Goldstein \& A. Dershowitz, Psychoanalysis, Psychiatry and the LaW 238-39 (1967).

117. Meehl, Psychology and the Criminal Law, 5 U. RicH. L. Rev. 1, 6 (1970) [hereinafter cited as Meehl]. See also Hall, Psychiatry and Criminal Responsibility, 65 YALE L.J. 761, 772 (1956). 
clinicians analyze the difficult practical questions of diagnosis, amenability to treatment, and prediction of future conduct, their theoretical differences undoubtedly account for many of their conflicting conclusions. ${ }^{118}$

Diagnosis of mental condition depends to a large extent upon the psychiatrist's perception of the patient's overt behavior and nonverbal communication during interviews, and on additional information concerning the patient's background and conduct which the psychiatrist obtains from collateral sources. ${ }^{119}$ - The diagnostic function is highly subjective, ${ }^{120}$ various characteristics of the examining psychiatrist or clinician may affect his perception of the patient and the integration of the observed data into a diagnostic formulation. For example, studies show that clinicians who reveal a high degree of authoritarianism on personality tests tend to find less pathology in their patients than those with opposite characteristics. ${ }^{121}$ Thus the more authoritarian the clinician, the less likely he will be to support a defense of insanity or to recommend hospitalization rather than imprisonment after conviction. Other studies have shown that age and nationality ${ }^{122}$ and peer group influence ${ }^{123}$ can affect diagnosis. And, of course, differences in theoretical orientation may result in differing diagnoses. ${ }^{124}$

118. See generally Diamond, supra note 14 , at 228 . The potential effect of different diagnostic schemes on the character of psychiatric testimony has been demonstrated. See Blocker v. United States, 288 F.2d 853, 874 (D.C. Cir. 1961) (Miller, C.J., dissenting).

119. F. Redich \& D. Freedman, The Theory and Practice of Psychiatry 197220 (1966); Salzman, Psychiatric Interviews as Evidence, 30 GEo. WaSH. L. REv. 853, $855-56(1962)$.

120. Ausubel, Personality Disorder is Disease, in T. ShefF, MENTax Illness and SOCIAL PROCESS 254, 259-60 (1965).

121. Gordon, Some Effects of Clinician and Patient Personality on Decision Making in a Clinical Setting, $31 \mathrm{~J}$. Consultang Psychology 477 (1967); Gordon, Some Effects ef Information, Situation, and Personality on Decision Making in a Clinical Setting, 30 J. Consulting Psychology 219 (1966).

122. Katz, Cole, \& Lowery, Studies of the Diagnostic Process, 125 J. PsychiATrY 937, $943-44$ (1969). For a discussion of the significance of these findings, see Zubin, Biometric Assessment of Mental Patients, in The Role and Methodology of Classification in Psychiatry and Psychopathology 353 (M. Katz, J. Cole \& W. Barton, eds. 1965).

123. Temerlin, Suggestion Effects in Psychiatric Diagnosis, in ThE MaknNG of a Mental Patient 230 (R. Price \& B. Denner eds. 1973).

124. The impact of theoretical differences on diagnosis is difficult to document. One knowledgeable observer has noted that those who are Kraepelinian in orientation, rather than psychoanalytically oriented, are "less inclined to probe deeply, inore inclined to accept uncritically surface manifestations, and are prone to interpret the legal criteria of imsanity in a narrowly restricted way." Diamond, supra note 14, at 228. According to Diamond, nost court-appointed psychiatrists are Kraepelinian il orientation. Id. See also A. Brookes, Cases and Materials on Law, Psychiatry and the Rights OF THE MENTALly Disabled A-55 (temporary ed. 1973). 
A further problem with diagnosis is that there is no general agreement that a particular symptom or group of symptoms evidences a particular diagnostic group, such as schizophrenia or manic-depressive reaction. ${ }^{125}$ One major study examining the relationship between symptom manifestation and inclusion in a particular diagnostic group conclued that "although relationships exist between symptoms and diagnosis, the magnitude of these relationships is generally so small that membership in a particular diagnostic group conveys only minimal imformation about the symptomatology of the patient."120 This finding led the author to observe: "Since the basis for diagnostic classification is ostensibly symptom manifestation, the question arises as to why such classification has been found to be reliable in spite of the fact that symptoms tend to occur with surprisingly comparable frequency across diagnostic groupings."127

The significance of bias and lack of clear definition of diagnostic categories may be examined in terms of the reliability of the diagnostic process. Reliability in this sense refers to the degree of concurrence among clinicians on the diagnosis of the same patient. ${ }^{128}$ In one of the few systematic studies of diagnostic reliability, Ash compared diagnoses made by three psychiatrists on the same patients at a government clinic. ${ }^{129}$ The patients were examined by the psychiatrists jointly, but the diagnoses were recorded independently. The three agreed on the specific diagnostic category ${ }^{130}$ in only 20 percent of the cases; two psychiatrists agreed on a diagnosis in another 49 percent of the cases. When only a general diagnostic category was considered, agreement

125. The most widely used diagnostic classification scheme is that contained in the Diagnostic and Statistical Manual, Mental Disorders, published in 1952 by the Ameri. can Psychiatric Association. F. Redlich \& D. Friedman, The Theory and Practicr OF Psychiatry 259 (1966).

126. Zigler and Phillips, Psychiatric Diagnosis and Symptomatology, in BeHAvion DisoRDERs 64, 72 (O. Milton ed. 1965).

127. Id. at 70-71.

128. Reliability must not be confused with validity. A thermometer may be highly reliable but low in validity; for example, it may consistently read exactly 20 degrees below the true temperature. Reliability, however, sets an upper limit on validity; a thermometer which gives different readings wheu exposed to substances at the same temperature cannot give a valid reading. Measurement of the validity of psychiatric diagnosis is virtually impossible because no reliable independent assessment of mental state is available with which to compare the diagnosis. Studies of the reliability of psychiatric diagnoses, however, give some rough indication of the upper level of validity. See, e.g., B. Kieinmuntz, Personality Mensurement 168 (1967).

129. Ash, The Reliability of Psychiatric Diagnoses, 44 J. Abnormal \& Soctal PsYchology 272 (1949).

130. The study utilized five general diagnostic categories: mental deficiency, psychosis, psychopathic personality, neurosis, and a category labeled "predominant personality characteristics." Each of these was in turn further divided into specific diagnostic categories, of which there were approximately 60 . Id. 
was higher. All three psychiatrists agreed in 46 percent of the cases; two psychiatrists agreed in another 51 percent of the cases; in only three percent of the cases did all three disagree. ${ }^{131}$ Ash made another rather sobering finding: In fully one-third of the cases, one psychiatrist found serious pathology, while the other two found the patient to be, with some qualifications, a normal individual. ${ }^{132}$ Moreover, the joint examinations may have inflated the levels of agreenent by allowing tacit communication among the psychiatrists.

The findings of later researchers have generally been consistent with Ash's findings. In general, researchers have found that the level of reliability, as measured by inter-psychiatrist agreement on specific diagnostic categories, is quite low, typically in the neighborhood of 32 percent. ${ }^{133}$ An important exception is that the rate of agreement on orgamic disorders is generally quite high, roughly 80 to 90 percent, because these usually involve braim damage which can be detected by

131. Id. at 274.

132. Id. at 275. Laing and Esterson contend that "even two psychiatrists from the same medical school cannot agree on who is schizophrenic independently of each other more than eight out of ten times at best; agreement is less than that between different schools, and less again between different countries." R.D. LAING \& A. EsTERSON, SANITY, MAdNess AND the Family 11-12 (Penguin ed. 1964).

133. For a survey of the literature see Beck, Reliability of Psychiatric Diagnoses, 119 AM. J. Psychiatry 210, 211-12 (1962) (hereinafter cited as Beck). Hunt, Wittson, and Hunt studied the rehiability of psychiatric diagnoses of naval enlisted men, finding an agreement on broad categories (psychosis, psychoneurosis, and personality disorder) of 54 percent. (The purpose of the psychiatric diagnoses was to determine suitability for continued service.) Hunt, Wittson, \& Hunt, $A$ Theoretical and Practical Analysis of the Diagnostic Process, in P. Hoch \& J. ZubIN, CURrent Problems IN Psychiatric Diagnosis 59 (1953). Another study compared the diagnoses of four psychiatrists and found an overall agreement rate comparable to that of the Hunt, Wittson, and Hunt study. Beck, Ward, Mendelson, Mock \& Erbaigh, Reliability of Psychiatric Diagnoses, 119 AM. J. Psychiatry 351 (1962). This marginal level of rehability in psychiatric diagnoses should not, however, be misinterpreted. It is important to note that studies in other fields of medicine have revealed similar levels of reliability as measured by agreement between physicians. For instance, one study of reliability in eliciting pulmonary symptoms found variations of between 50 and 400 percent (depending on the particular symptom) of the rates at which various clinicians recorded the symptom. Cochrane, Champman, \& Oldham, Observers' Errors in Taking Medical Histories, 260 LANCET 1007 (1951). A study of the disagreement in interpretation of chest X-rays placed this rate at 30 percent; however, some 40 percent of the positive $X$-rays were incorrectly read as negative, which of course could lead to significant consequences in terms of providing needed treatment. Garland, The Problem of Observer Error, 36 BULl. N.Y. ACADEMY of MEDICINE 570 (1960). In a study of tonsil diagnosis, one group of doctors identified one-half of a group of school children as needing tonsilectomies. A second group of doctors examined the remaining children and concluded that 45 percent of thein needed tonsilectomies. Those of the second group found not to require surgery were examined by a third set of doctors, who concluded that one half were in need of tonsilectomies. These results were exactly what would have been predicted had each doctor decided randomly. Baldwin, Pseudoting Pediatricia, 232 NEW ENGLANd J. Medicine 691 (1945). 
physical tests witl proven high reliability. ${ }^{134}$ Reliability for general diagnoses falls in between, with any two psychiatrists agreeing only about 55 percent of the time. ${ }^{135}$

Clinicians are often called upon in criminal cases to predict amenability to treatment or future conduct such as dangerousness. ${ }^{130}$ The evidence of reliability liere is similarly disheartening. In 1970, Meehl stated flatly that "the painful fact of the inatter is that we do not know how to treat, or 'cure,' or rehabilitate, or reform criminal offenders. What scientific research there is . . . does not indicate that we have a technology of criminal prevention or reform available at the present time." 137 A survey of the literature indicates that psychiatrists have, at best, a narginal capacity to predict "dangerousness" or other forms of unusual behavior, such as suicide. ${ }^{138}$ Derslowitz $^{130}$ and Meehl ${ }^{140}$ botli note that clinical prediction is less reliable than statistical methods of prediction.

134. V. NoRris, MENTAL IIINESS IN LoNDON (1959); H. SCHMmT and C. FondA, The Reitabitity of Psychiatric Diagnosis 263-64 (1963); Beck, supra note 132, at 211; Hunt, Wittson, \& Hunt, supra note 132, at 63-64.

135. Beck, supra note 132, at 211.

136. The prediction of treatability is inescapably tied to the broader issue of the effectiveness of treatment in general, about which the evidence is equivocal at best. See the extensive compilation of studies cited in Meehl, supra note 115, at 26 n.19; Schreiber, Indeterminate Therapeutic Incarceration of Dangerous Criminals: Perspectives and Problems, 56 VA. L. Rev. 602, 626 n.135 (1970) [hereinafter cited as Schreiber]. When the question is narrowed to the treatability of criminal offenders, the evidence is generally negative. See Bailey, Correctional Outcome: An Evaluation of One Hundred Reports, 57 J. Crrm. L.C. \& P.S. 153 (1966); Christie, Research Into Methods of Crime Prevention, in 1 Collected Studies in Criminological Resenrch 55 (1967); Hood, Research on the Effectiveness of Punishments and Treatments, in 1 Colifetred Studies In Crminological Research 73 (1967); Schreiber, supra, at 626.

Relatively few studies have addressed themselves to the ability of clinicians to predict treatment outcome, which depends not only on whether a treatment works in general, but whether its effect can be predicted for particular individuals. One of the few studies on the prediction of treatment outcome gives little cause for optimism. Sec Dinitz, Lefton, Angrist, \& Pasamanick, Psychiatric and Social Attributes as Predictors of Case Outcome in Mental Hospitals, in T. ShefF, Mental Illness ANd Socul ProcEsS 119 (1967).

137. Meehl, supra note 115, at 4 (footnote omitted).

138. McGee, Objectivity in Predicting Criminal Behavior, 42 F.R.D. 192, 196 (1968). Rosen, Detection of Suicidal Patients: An Example of Some Limitations in the Prediction of Infrequent Events, 18 J. Consulting Psychology 397 (1954); Sawyer, Measurement and Prediction, Clinical and Statistical, 66 Psxchological Bull. 178 (1966); Wenk, Robison, \& Smith, Can Violence Be Predicted?, 18 CRIME aND DelinQUENCY 393 (1972); Wolfgang, Violence and Its Relation to Sentencing, 46 F.R.D. 533,551 (1969).

139. Dershowitz, The Psychiatrist's Power in Civil Commitment: A Knifc That Cuts Both Ways, 2 Psychology Today 43, 47 (1969).

140. Meehl, supra note 115, at 9. See also P. MeEhl, Clinical Versus Statistical Prediction (1954). 
The most dramatic example of the difficulties of predicting dangerousness occurred in New York following the decision of the United States Supreme Court in Baxstrom v. Herold. ${ }^{141}$ The Court held unconstitutional a New York procedure for holding a prisoner in an institution for the "criminally insane" after his sentence had been fully served. The state then transferred all 992 persons who were being so held to a civil hospital, although they previously had been labeled too dangerous to be placed there. Only seven of this group of 992 had to be returned to the institution for the criminally insane because of subsequent manifestations of dangerousness. ${ }^{142}$ Within a year, 176 were fully discharged, 147 to their hoines and the rest to other hospitals. ${ }^{143}$ A follow-up study by a distinguished committee of New York lawyers indicated that these results were "another instance of institutionalized expectations putting blinders on our perceptions." ${ }^{144}$

\section{The Swedish Experience}

The Swedish study illustrates similar defects in the psychiatricadministrative decision-making model. The data suggest, for instance, that persons with similar, if not identical, medical-psychiatric backgrounds and symptoinatology are often placed in different categories notwithstanding the lack of meaningful differences. Secondly, classification decisions are frequently tied to nonclinical factors entirely divorced from the avowed rationale of a particular classification. Since both of these defects concern the classification process, it may be helpful to clarify the various categories with which Swedish psychiatrists must work before further discussion.

The controlling provision of the new Swedish penal code establishes three broad categories of abnormality. ${ }^{145}$ These are "sinnessjukdom" (mental disease), "sinnesslöhet" (mental retardation), and "jämställd nned sinnessjukdom" (equivalent to mental disease). While the term "mental disease" has not been defined by statute or judicial decision, the legislative history suggests that the term was intended to encoinpass the generally recognized psychotic class of disorders. ${ }^{146}$ The present study indicates, however, that the operational

141. 383 U.S. 107 (1966).

142. Schreiber, supra note 135 , at 619-20.

143. Id.

144. Special Committee on the Study of Commitment Procedures and the Law Relating to Incompetents, Mental Illness, Due Process and the Criminal Defendant 227 (1968) (study by the Association of the Bar of the City of New York), cited in Schuster v. Herold, 410 F.2d 1071, 1086 (2d Cir. 1969).

145. BrB, supra note 6 , ch. 31 , § 3 .

146. Commentary on Royal Proposal No. 207 of March 2, 1945 at 83; [1945] Prop. (Swed.). Additional guidance is provided by the Mental Health Law of 1966, 
meaning given to the "mental disease" category extends well beyond the psychotic class. In fact, approximately one-third of those classified as suffering from "inental disease" were diagnosed as having abnormalities not within the psychotic class of disorders, as defined by the Diagnostic and Statistical Manual, Mental Distorders. ${ }^{147}$ For instance, 10 percent were diagnosed as having acute brain syndromealcoholic intoxication, six percent were in the general category "psychoneurotic disorders," and 11 percent had personality disorders (drug addiction and other disturbances).

Of the three categories established under the code, the "mental retardation" class presents the fewest definitional problems, for the legislative history makes it plain that this category is to encompass those whose intelligence quotient is below $65 .^{148}$ The study data suggest that with few exceptions this appears to be the operational meaning given to the category.

Neither the wording of the statute nor its legislative history provides much guidance to the intended scope of the "equivalent to mental disease" category, beyond an intent to expand the reach of chapter 33-2 beyond the traditional psychotic class of disorders. The extent to which this class was intended to cover neurotic conditions or personality disorders is not altogether clear. What legislative history is available suggests that while some sociopathic conditions can qualify, they must be either congenital or organically based. ${ }^{140}$ Similarly, the authoritative commentary indicates that certain "severe neurotic" conditions can also qualify. ${ }^{150}$ A more recent commentary by members of

regulating civil commitment, in which the requisite degree of mental abnormality is defined in terms of "psykisk sjukdom." Mental Health Law of 1966, supra note 10, $\S$. According to the one legislative advisory committee, this difference in language was intended to evidence the fact that the standard under 33-2 is narrower and was designed to encompass only the psychotic class of disorders, whereas the broader term "psykisk sjukdom" may include certain neurotic conditions. Commentary on Royal Proposal No. 53 of March 4, 1966 at 47; [1966] Prop. (Swed.).

147. American Psychiatric Ass'n, Diagnostic and Statisticat Manual, MenTAL DISORDERS (1952).

148. Commentary on Royal Proposal No. 207 of March 2, 1945 at 83; [1945] Prop. (Swed.).

149. Id. at 79. While psychiatry in the United States does not emphasize etiology in classifying mental disorders, Swedish and Scandinavian psychiatry in general tend to einphasize causative factors. Most mental disorders, including schizophrenia, are divided into two classes, one predominantly biological, the other environmental in origin. This formulation of causation finds expression in the most cominonly used classification scheme under which disorders are characterized as either endogenous or exogenous in origin. See Langfeldt, Scandinavia, in Contemporary EURopran PSYCHIATRX 223, 228 (L. Bellak ed. 1961).

150. Commentary on Royal Proposal No. 207 of March 2, 1945 at 79; [1945] Prop. (Swed.). 
the original legislative advisory committee elaborates further that only those neurotic disorders which are chronic, debilitating, and result in profound changes in the personality of the individual can qualify. ${ }^{151}$

Given the generality of the governing language, the psychiatrists and judges who inust apply these provisions will effectively define the standard. Examining the diagnostic groupings of those placed in the "equivalent" category, it is apparent that it has been broadly construed. Fifty-two percent were classified as "personality disorder" type. The next largest diagnostic category, 19 percent, coinprised neurotic conditions of various types. The remaining 27 percent of the "equivalent" class included various diagnostic categories, with alcoholism (5.5 percent), senile and presenile denientia (3.8 percent), schizophrema (3.8 percent), and psychosis associated with intracranial infection ( 3.4 percent) being the niost numerous. The principal difference between the "equivalent" and the "inental disease" categories is that the latter includes a far greater percentage of persons classified within one of the psychotic reaction categories (71 percent versus 13.4 percent).

\section{a. Lack of Inter-Category Differences}

The Swedish study reveals the greatest lack of meaningful psychiatric-1nedical inter-group differences when findings of "no niental disease" are compared with "equivalent to mental disease" findings. A comparison of these two theoretically different classes reveals a striking similarity of diagnostic groupings assigned to them. Sixty-eight percent of the "equivalent" category were diagnosed as personality disorder or neurotic condition cases. Seventy-four percent of the "no disease" category were similarly classified. This considerable overlap raises the question of what criteria led to the placement of an offender in one rather than the other category. An analysis of inultiple variables discloses a significant difference with respect to only one-the incidence of prior psychiatric hospitalization. As the table below indicates, 58 percent of the "equivalent" class had a history of prior psychiatric hospitalization, as compared with only 23 percent of the "no disease" class. This variance nnay have been caused by valid differences anrong persons exainined that were not disclosed by the forensic-psychiatric examination report; but it also may reflect a hesitancy on the part of psychiatrists to classify as free of inental disorder persons previously hospitalized.

151. III Kommentarer TiLl BrotTSBalkeN at 258 (1967). Since 1965, only one appellate decision has made reference to the "equivalent" class of disorder. Judgment of Dec. 9, 1968, [1968] N.J.A. 471 (Swed.). The court, however, did not address itself directly to questions of definition and scope. 
Incidence of Previous Psychiatric Care And Recommendation of Forensic Psychiatric Agencies

\begin{tabular}{|c|c|c|c|c|c|c|c|}
\hline & \multicolumn{7}{|c|}{ Previous Contact } \\
\hline & 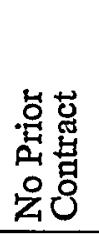 & 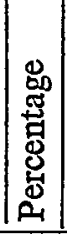 & 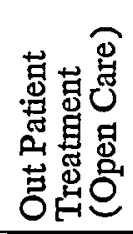 & 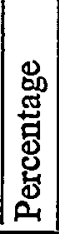 & 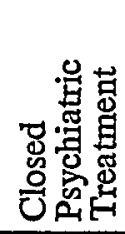 & 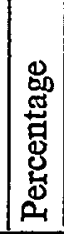 & 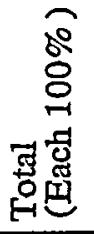 \\
\hline Mental Disease & 15 & 20 & 9 & 12 & 52 & 68 & 76 \\
\hline Retarded & 8 & 42 & 4 & 21 & 7 & 37 & 19 \\
\hline Equivalent & 31 & 23 & 25 & 19 & 77 & 58 & 133 \\
\hline No Mental Disease & 206 & 58 & 68 & 19 & 83 & 23 & 357 \\
\hline Total & 260 & 44 & 106 & 18 & 219 & 37 & 585 \\
\hline
\end{tabular}

\section{b. Reliance on Nonclinical Factors}

As previously indicated, in Sweden there are three categories of findings regarding mental abnormality which authorize hospitalization rather than imprisonment if the psychiatrist also finds the defendant in need of treatment. ${ }^{152}$ The case data revealed that once an offender was found to be within one of the three categories, there were no discermible criteria related to his mental condition which explain the conclusion of "need for treatment" in 346 cases and "no need for treatment" in 671 cases. The most significant difference between the two groups was the type of crime committed or, nore specifically, the degree of violence involved.

An offender who committed a crime of violence (arson, rape, aggravated assault, or murder) while in one of the states of mental abnormality was nearly certain to be found in need of treatment. Ninety percent of those charged with arson who inet a mental abnormality criterion were found to be in need of treatment, and similar percentages prevailed for those charged with rape and assault. In cases of aggravated assault and murder, all offenders who were diagnosed as fitting one of the categories of mental abnormality were also found to be in need of treatment. These results in cases of violence can perhaps be explained, because chapter 33-2 of the penal code precludes imprisonment of persons who fall within one of the designated classes of mental abnormality. Psychiatric hospitalization represents the only authorized form of incarceration for even violent mentally abnormal offenders. But this indicates that factors other than medical ones-factors evident even to lay jurors-greatly influence psychiatric findings.

152. See text accompanying note 144 supra. 
The only other significant factor which consistently appeared to have influenced the recommendation of "need for treatment" is likewise nonmedical: the number of prior convictions. As indicated by the table below, in both the "mental disease" and "equivalent" categories, those found to be in need of treatment had significantly greater numbers of prior convictions than those found not to need treatment. If one assumes that prior conviction involved prior imprisonment, it is not surprising that psychiatric hospitalization was more likely to be selected when there was a history of prior imprisonment which failed to rehabilitate or deter.

\section{RECOMMENDATION OF MEDICAL BOARD AND INCIDENCE OF PRIOR CONVICTIONS}

Diagnosis and Recommendation Number Number of Prior Convictions

\begin{tabular}{lcccc} 
& $\begin{array}{c}\text { of } \\
\text { Patients }\end{array}$ & Range & Median & Average \\
\cline { 3 - 5 } & 96 & $0-14$ & 1 & 1.8 \\
\hline Mental Illness with & 22 & $0-8$ & 0 & 1.1 \\
$\begin{array}{l}\text { Need of Treatment } \\
\text { Mental Illness without }\end{array}$ & 23 & $0-5$ & 1 & 1.3 \\
$\begin{array}{l}\text { Need of Treatment } \\
\text { Retarded with }\end{array}$ & 8 & $0-5$ & 1 & 2.0 \\
$\begin{array}{l}\text { Need of Treatment } \\
\begin{array}{l}\text { Retarded without } \\
\text { Need of Treatment }\end{array}\end{array}$ & 204 & $0-23$ & 2 & 3.7 \\
$\begin{array}{l}\text { Equivalent with } \\
\text { Need of Treatment }\end{array}$ & 34 & $0-10$ & 0 & 1.4 \\
$\begin{array}{l}\text { Equivalent without } \\
\text { Need of Treatment }\end{array}$ & 412 & $0-40$ & 2 & 3.1 \\
$\begin{array}{l}\text { No Mental Disease, } \\
\text { No Need of Treatment }\end{array}$ & 799 & $0-40$ & 2 & 3.1 \\
\hline \multicolumn{1}{c}{ TOTAL } & &
\end{tabular}

To summarize, the empirical data developed in Sweden reveal that in two critical areas, determining abnormality and deciding on the need for treatment, the only discernible criteria consistently influencing the findings of psychiatrists are the nature of the crime, prior convictions, and prior hospitalization. These factors arguably have some relation to the issue of mental condition. But certainly they are factors that judges and jurors are as capable of assessing as are psychiatrists. ${ }^{163}$

153. Of course the psychiatrists may have relied on other factors which were not disclosed by the forensic-psychiatric reports. But if that were true, psychiatrists would be consistently depriving the de jure decision maker, the court, of information about the true bases for their recommendations and there is no reason to assume this is the practice.

A distinguished American jurist recently noted that "after attending a two day conference on prediction of dangerousness a few years ago, I learned that if a person com- 


\section{B. Impartiality and Institutional Bias}

\section{The United States}

The issue of "impartiality" in psychiatric decisionmaking has two aspects. One assertion, difficult to document but generally believed by defense counsel to be true, is that court-appointed psychiatrists are inore likely to be favorable to the prosecution than to the defense. ${ }^{15 \cdot}$ One commentator attributes this bias to the fact that court-appointed experts are not chosen at random but are a self-selected group whose training and orientation inclines thein to narrow interpretations of legal criteria pertaiming to mental abnormality. ${ }^{155}$

Another factor affecting impartiality, which perhaps helps explain a prosecution bias, is the institutional bias of psychiatrists connected with public psychiatric hospitals. State inental hospitals face the constant problein of overcrowding, and doctors administering these hospitals are often able to admit only persons who are so debilitated that they are unable to function outside an institution. ${ }^{156}$ Such functionally disabled persons are then classified as psychotics. This method of classification may later affect the psychiatrist's judgment whon he is called upon to testify concerning an insanity defense, making him more likely to find insanity only when the defendant's mental condition is so debilitating that the doctor would hospitalize under ordinary procedures. This imstitutional bias has great impact on sanctioning procedures because the standard for the insanity defense does not necessarily require a debilitating condition.

\section{Sweden}

There is also evidence of institutional bias within the Swedish systein. The only available study of the comparative performance of various forensic-psychiatric examination centers discloses that in a fouryear period an examination clinic associated with a conventional psychiatric hospital in the south of Sweden found the requisite degree

mitted the same crime fifteen times, he was more likely to do it again than a person who was only a three times, four times or eight times repeater. I submit, for that insight, you don't need to be an M.D. or have Board certification." Address by Chief Judge David L. Bazelon, Joint Meeting of the Cleveland Bar Association and the Cleveland Psychiatric Society, Oct. 12, 1973.

154. MatThews, supra note 14, at 39; Diamond, supra note 14 , at 229 . But see McGarty v. O'Brien, 188 F.2d 151 (1st Cir.), cert. denied, 341 U.S. 928 (1951), in which the Massachusetts examination procedures under the Biggs Law were characterized as having been performed by "competent persons, free from any predisposition or bias and under every inducement to be impartial and to scek for and ascertain the truth." Id. at 155.

155. Diamond, supra note 14 , at 228.

156. MaTTHEws, supra note 14 , at 41-42. 
of mental abnormality in 68 percent of the cases processed. ${ }^{157}$ By comparison, an examination clinic associated with a prison facility in Stockholm froin only 28 percent of the patients referred to it to be mentally abnormal under the statute. Since assignment to one examination clinic rather than the other is strictly a function of the offender's residence, it is difficult to escape the conclusion that an institutional bias influenced the diagnostic and classification processes.

\section{IV}

\section{Considerations Beyond "Scientific" Diagnosis of MENTAL CONDition}

\section{A. The United States Tradition}

Even if psychiatric evaluations displayed a higher degree of reliability than they do, the question of whether the final judgment about a person's mental condition should be effectively left to psychiatrists would still remain. In the United States, where the tradition of jury trial in criminal cases is so strong that it has become an element of due process of law, ${ }^{158}$ that question goes far beyond purely medical issues. This contrasts vividly with the Swedish system, which perceives the question of mental condition as essentially a medical-scientific one to be answered by experts. In Sweden, the abolition of the insanity defense eliminated issues of moral culpability; mental condition goes only to the decision whether the offender should be imprisoned, hospitalized, or set free.

In the American context, the debate over the proper test for the insanity defense reflects the difficulties of balancing the respective roles of psychiatrist and jury. The debate has generally accepted the premises that social objectives beyond pure medical questions are relevant to a determination of insanity, and that the expertise of psychiatrists and psychologists can assist jurors in making their decisions. Dean Goldstein offers what is perhaps the best expression of the proper balance to be struck:

So long as we do not know what really "causes" crime, the insanity defense will have to be framed in a way which permits juries to express the feelings of the community on the subject of responsibility. Perhaps when there are experts who do know, the matter can be given over entirely to them, or the question can be framed for the jury in precise terms. But in the long meanwhile, we shall have to be content with a concept of insanity very much like the one we now

157. Kinberg, The Swedish Organization of Forensic Psychiatry, 44 J. CRIM. L.C. \& P.S. 135,139 (1953).

158. Duncan v. Louisiana, 391 U.S. 145 (1968). 
have. That concept treats insanity as a legal standard, a loosely framed guide for a process in which particular cases are reconciled with the hard-to-state purposes of substantive law. Those purposes are, in turn, fixed by bodies which are authorized, through a political process, to speak for the society-legislatures in some instances, courts in others, and juries ultimately. ${ }^{150}$

Juries act as social consciences, and psychiatrists cannot perform this function in their stead. A widely publicized "mercy killing" trial in 1973 illustrates Jerome Hall's comment that "a criminal trial may seek to ascertain whether the accused in fact was competent to make a moral decision; many psychiatrists insist they are wholly unable to aid the solution of this issue."100 The defendant had shot and killed his brother in a hospital bed, responding to the brother's pleas to kill him because he was physically unable to do it himself. (The brother had been imjured in a motorcycle accident, was paralyzed from the neck down, was in great pain, and had no chance of improvement with a likelihood of deterioration until death). After conflicting psychiatric testimony was presented in an adversary context about the defendant's inental capacity at the time of the shooting, the jury acquitted him on grounds of temporary insanity. ${ }^{101}$ Only a jury could have resolved the conflicting psychiatric testimony and at the same time acted as the public conscience.

In sum, the decision whether a social offender should be imprisoned, hospitalized, or set free because of his mental condition should not be relegated to psychiatrists-first because their findings are not sufficiently reliable and, even more important, because considerations of broad societal interests beyond the expertise of the psychiatrist should underlie and influence the decision-making process.

\section{B. The Shift to Psychiatric Decisionmaking}

The long-range trend in the United States has been to shift the power to decide a defendant's mental condition from juries and judges to psychiatrists. In contrast to Sweden, where the allocation of decisional authority to psychiatrists is the consequence of a purposeful legislative policy, ${ }_{e}^{162}$ the shift in the United States has not been deliberately mandated by either legislatures or courts. ${ }^{163}$ Rather, it has been

159. GoLDSTEIN, supra note 9, at 91.

160. Hall, Psychiatry and Criminal Responsibility, 65 YALE L.J. 761, 770 (1956).

161. N.Y. Times, Nov. 6, 1973, at 1, col. 6.

162. See text accompanying note 31 supra.

163. Resolution of the insanity defense as part of the determination of criminal responsibility may be a constitutionally required jury function. See Goldstein, supra note 9, at 223. In those states that provide a right to a jury in civil commitment cases, there may also be a right to jury determination of the commitability of a criminal de- 
the result of adopting procedures for court appointment of expert psychiatric witnesses. Although introduced to assist lay fact-finders and proinote efficiency in the decisionmaking process, the court-appointed psychiatrist is increasingly the de facto decision maker. ${ }^{164}$ The proposed Criminal Code Reform Act codifies this trend toward reliance on government psychiatrists as the effective decision makers for the federal criminal system. The proposed Act authorizes the court to appoint a panel of psychiatrists whenever mental condition is in issue ${ }^{185}$ and receive written psychiatric reports which include the psychiatrists' opinions on the ultimate questions as to the defendant's mental condition. ${ }^{100}$ The proposed code makes no explicit reference to testimony by the panel meinbers, but federal judges have power to cail "court witnesses."167

It may be argued that the proposed code iniplicitly authorizes admission of the psychiatric repont, including diagnosis and opinion as to mental condition, without the testimony of the psychiatrist who prepared it. It is also arguable, based primarily on decisions in civil cases, that the report is admissible under the busimess records exception to the hearsay rule. ${ }^{188}$ These arguments sliould be rejected

fendant found not guilty by reason of insanity. While this issue has not been resolved by the Supreme Court, the Court of Appeals for the District of Columbia has held that the full procedural safeguards of civil commitment, including the right under local law to a jury trial, must be accorded the criminal defendant acquitted by reason of insanity. Cauneron v. Mullen, 387 F.2d 193 (D.C. Cir. 1967); Bolton v. Harris, 395. F.2d 642 (D.C. Cir. 1968). There remains the question of whether there is a federal constitutional right to a jury trial before commitment to a mental institution, even if state law does not provide for juries in civil commitments.

164. See text accoinpanying notes 107-111 supra.

165. S. 1400 , 93d Cong. 1st Sess. $\$ \$ 4221$ (b), 4222(b), 4224(b) (1973).

166. For example, when the issue is the defeudant's mental condition at the tine of the offense charged, the Act provides that:

The psychiatrists desiguated by the court shall file with the court, and provide the defendant and the United States Attorney with copies of reports which include the defendant's history and preseut symptoms and the psychiatrists' findings, a description of the psychological and niedical tests einployed and their results, and their opinions as to diagnosis, prognosis, and whether the defendant was insane at the time of the offense charged.

S. 1400, 93d Cong., 1st Sess. $\$ 4221$ (c) (1973).

167. Advisory Committee Notes to Rule 614, Proposed Rules of Evidence for the United States Courts and Magistrates (1972).

168. 28 U.S.C. $\$ 1732$ (1970). The case law interpreting the statute's applicability to psychiatric reports has been collected and analyzed in United States v. Bohle, 445 F.2d 54 (7th Cir. 1971).

The business records exception rests on the premise that regularly kept records are usually reliable because the record keeper is relying on them in the usual course of his business, because they are often subject to systematic checks for accuracy, and because they are not made in contenplation of hitigation. J. MCCoRMrCr, Evidence $\$$ 306 (2d ed. 1972); Advisory Committee Notes to Rule 803(6), Proposed Rules of Evidence for the United States Courts and Magistrates (1972). The psychiatrist's report to the court, however, has no independent value to the maker of the report, is not sub- 
whenever confinement in a prison or hospital is at stake, at least as to those portions of the report containing diagnostic opinion or opinion on whether the defendant's mental condition conformed to the relevant legal standard. The varied theoretical approaches applied by psychiatrists and the low reliability of psychiatric diagnosis make the opportumity for full cross-exaunination of any psychiatric opmion indispensable. Moreover, the use of such reports in criminal cases or commitment proceedings would raise issues of deprivation of sixth amendment and due process rights. ${ }^{160}$

\section{CONCLUSION}

Since the decision-making function of the jury is distorted when a court-appoimted psychiatrist is identified as such and his testimony accepted as impartial, it is iniportant to use such expert testimony carefully; the adversary process can be maintained through relatively simple instructions to the psychiatrist-witness to avoid any mention that he was appointed or employed by the court. ${ }^{170} \mathrm{He}$ should also be cautioned to avoid references to employment at state imstitutions known to the public, although such information inay have to be revealed to establish expertise or on cross-examination.

If the determination of the defendant's mental condition is for the judge, there is no practical method of maintaining an adversary format if the judge believes appointed psychiatrists to be impartial. This may be especially true if the judge appoints the psychiatrist himself. (The general practice is to refer the defendant to a state mental institution or the court's own chimic.) Even if a court administor rather than the judge chooses a psychiatrist from a panel, it will usually be apparent to the judge wlio the court-appointed psychiatrist is, particularly when lie is the only psychiatric witness. Judges will also recognize appoimted psychiatrists who make frequent court appearances. The

ject to systematic review for accuracy and, by its nature, is prepared for litigation, although not in the usual adversary manner. Moreover, in civil cases involving hospital records, the courts have permitted hearsay opinions only of "ordinary diagnostic findings customarily based on objective data and not presenting more than average difficulty of interpretation; and have rejected diagnostic opinions which are speculative." J. MCCORMICK, EVIDENCE § 314 (2d ed. 1972). McCormick describes records of psychiatric diagnosis as borderline cases; finding that "most courts will nevertheless permit the imtroduction of the record," but citing only civil cases. Sec id. at 732, n.9. McCormick recommends allowing use of the report only if the declarant is produced for cross-examination.

169. See Phillips v. Neil, 452 F.2d 337 (6th Cir. 1971), cert. denied, 409 U.S. 884 (1972); accord, Denton v. Kentucky, 383 S.W.2d 681 (Ky. 1964). But see Richardson v. Perales, 402 U.S. 389 (1971); Dutton v. Evans, 400 U.S. 74 (1970).

170. Faced with the analogous problem of avoiding references to the defendant's insurance coverage in personal mjury cases, the courts have fashioned the "investigator for the defense" eupliemism for the insurance claim agent. 
only remedy may be through cross-examination and contradictory testimony from a defense psychiatrist.

To maintain truly adversary proceedings and permit effective litigation of issues of mental condition, the defendant must have an imdependent psychiatrist, not only to testify but also to advise him and his attorney. "He will need his aid in determining the kinds of testimony to be elicited, the specialists to be consulted, and the areas to be explored on cross-examination of opposing psychiatrists."171 Court-appointed psychiatrists who examine a defendant and report as impartial experts cannot fulfill these functions.

Some defendants with adequate means can litigate psychiatric issues in an adversary context by calling their own experts to counter those appointed by the court. But for inost defendants psychiatric experts are too expensive, and they must be provided at public expense, if at all. Unless society is willing to provide defendants with the means for obtaining independent expert witnesses, ${ }^{172}$ their freedom and the conditions of their incarceration will turn on the opinions of psychiatrists employed by the government, and there will be hittle chance for the adversary process to expose conflicting expert views and disclose all the factual data a judge or jury needs to make an independent evaluation.

The lack of consistency ainong psychiatrists as to theory, diagnosis, and prediction of future conduct must be reflected in the procedures by which psychiatric testimony is presented to the judge and jury. Traditional adversary procedures are the best for exposing differences in professional judgments. The oft-decried "battle of the experts" is, in fact, particularly appropriate where the experts so often disagree. As Goldstein and Fine have remarked about the adversary system:

171. Goldstein \& Fine, supra note 169 , at 1066 . See United States v. Chavis, 476 F.2d 1137 (D.C. Cir. 1973).

172. At present an indigent defendant has no generally recognized constitutional right to the assistance of independent psychiatric experts who may be necessary to his defense. See United States ex rel. Smith v. Baldi, 344 U.S. 561 (1953); Proctor v. Harris, 413 F.2d 383 (D.C. Cir. 1969); McGarty v. O'Brien, 188 F.2d 151 (1st Cir.), cert. denied, 341 U.S. 928 (1951). Several state courts have suggested that in some circumstances assistance of an expert provided by state funds is constitutionally required. See State v. Green, 55 N.J. 13, 258 A.2d 889 (1969); State v. Taylor, 202 Kan. 202, 447 P.2d 806 (1968); People v. Watson, 36 Ill. 2d 228, 221 N.E.2d 645 (1966). These cases suggest that it is a constitutional violation to have no psychiatric evaluation made of the indigent defendant so that the defendant has no opportunity to offer any expert testimony as to mental condition. But most states provide some form of psychiatric evaluation when mental condition is in issue, usually by psychiatrists affiliated with state institutions. No case has been found holding that an indigent defendant has a constitutional right to payment of a defense psychiatrist if the court has appointed an "impartial" psychiatrist. 
In such a system, knowledge is presumed to be finite. Only a limited category of incontrovertibles-that of judicial notice-exists. The "impartial expert" intrudes upon the model of the ineluctably fallible man since his is the only expert testimony the state is obligated to provide. ${ }^{173}$

All of this is not to suggest that psychiatrists should have no role in determining whether an individual meets a legal standard of sanity or competence. By training and experience, psychiatrists have heightened powers of observation and the ability to place human behavior within a meaningful context. ${ }^{174}$ Judges and juries need their assistance and should receive it. But our study of Sweden's use of psychiatric experts following its abolition of the insanity defense has reinforced our conviction that these crucial determinations cannot yet be reliably made by psychiatrists. As Justice Frankfurter observed, the science of psychiatry "has not yet achieved the finality of judgment."175

173. Goldstein \& Fine, The Indigent Accused, The Psychiatrist, and The Insanity Defense, 110 U. PA. L. REv. 1001, 1075 (1962).

174. Dean Goldstein also sees a vital role for psychiatrists. "No professional group is better qualified to make ... . [an] estimate of the mental state of the accused." Goldstein, The Psychiatrist and the Legal Process: The Proposals for an Impartial Expert and for Preventive Detention, 33 AM. J. ORTHOPSYCHIATRY 123, 126 (1963).

But this role is to be exercised in an adversary context where the parties' attorneys can highlight the "strengths and weaknesses" of the testimony of the psychiatrist and "make clear the particular relevance of his expertise to the task at hand." Id. at 127.

175. Greenwood v. United States, 350 U.S. 366, 375 (1956).

The role of psychiatric evidence in the criminal process has been aptly summarized:

Expert testimony performs a valuable function in explaining complex and specialized data to the untutored lay mind. When the experts have made available their knowledge to aid the jury or the Court in reaching a conclusion, their function is completed. The opinions and judgments or inferences of experts even when unanimous and uncontroverted, are not necessarily conclusive on the trier of the facts and may be disregarded when, in the light of the facts adduced, such judgments, opinions or inferences do not appear valid. The jury, in determining the probative effect to be given to expert testimony is not to disregard its own experience and knowledge and its collective conscience.

United States v. Pollard, 171 F. Supp. 474, 478 (E.D. Mich. 1959), rev'd, 282 F.2d 450 (6th Cir. 1960). 